\title{
Pemilihan Lokasi Kantor Menggunakan Metode Analytical Hierarchy Process (AHP) (Studi Kasus: PT. Monang Sianipar Abadi Surakarta)
}

\author{
Aditha Capryani $^{* 1)}$, Alviandi Wahyu Nugroho ${ }^{2)}$, Virda Hersy Lutviana Saputri ${ }^{3)}$ dan \\ Yuniaristanto ${ }^{4)}$ \\ ${ }^{1), 2), 3)}$ Program Studi Sarjana Teknik Industri, Fakultas Teknik, Universitas Sebelas Maret, Surakarta, \\ 57126, Indonesia \\ 4) Grup Riset Rekayasa Industri dan Tekno Ekonomi, Program Studi Teknik Industri, Universitas Sebelas \\ Maret, Surakarta, 57126, Indonesia
}

\begin{abstract}
PT. Monang Sianipar Abadi (MSA Kargo) Surakarta had experienced problems such as delays in delivery of goods. One cause of the delay problem is there are two places for the delivery of goods, which is headquarters in Pawulan, Colomadu and warehouse located near Airport Adisumarmo. In connection with these problems, improvements are expected to tackle the problem of delay delivery of goods caused by places for the delivery of goods. Repairs carried out by determining the best location to be the location of office shipping the items. Determination of the place of delivery of goods using fast and accurate method is the method of Analytical Hierarchy Process (AHP). The process of determining the place of delivery of goods based on four criteria, namely within the main warehouse (warehouse near the plane at the airport Adisumarmo), ease of access by customers, building area, and the availability of facilities. Based on the results obtained total global priority, then the decision can be taken the nicest locations in determining the location of the office is the location S2 is in Pawulan, Colomadu because it has the highest total global priorities, namely 0.638. However, the site has the disadvantage that the distance is far enough away from the main warehouse so it can be added to a solution is by adding a fleet of delivery.
\end{abstract}

Keywords: analytical hierarchy process, determining location, delivery of goods, fleet additions

\section{Pendahuluan}

Industri jasa pengiriman di Indonesia semakin berkembang pesat seiring dengan perkembangan teknologi. Industri jasa pengiriman adalah suatu industri jasa penunjang yang dibutuhkan oleh konsumen sekarang ini. Industri jasa pengiriman memberikan pelayanan yang berupa mengirimkan atau mengantarkan suatu barang dari suatu lokasi ke lokasi yang lain (lokasi yang dituju). Keberadaan industri jasa pengiriman dapat mempermudah proses bertukar informasi melalui surat, dokumen, berkas serta membantu berkirim barang misalnya baju, makanan, dan sebagainya.

PT. Monang Sianipar Abadi (MSA Kargo) merupakan salah satu perusahaan jasa pengiriman barang. PT. Monang Sianipar Abadi (MSA Kargo) memiliki dua jenis pegiriman barang, yaitu melalui jalur udara dan melalui jalur laut. Pada MSA Kargo Surakarta, pengiriman barang terfokus pada pengiriman barang melalui jalur udara. PT. Monang Sianipar Abadi (MSA Kargo) Surakarta pernah mengalami permasalahan berupa keterlambatan pengiriman barang. Hal tersebut disebabkan oleh beberapa faktor, antara lain kurang tanggapnya karyawan dalam menangani pengiriman, kerjasama dan komunikasi yang kurang dari karyawan, minimnya

\footnotetext{
${ }^{*}$ Correspondance : virdahersy@gmail.com
} 
armada, biaya transportasi yang mahal, jadwal pengiriman tidak terstruktur, dan terdapat dua tempat untuk pengiriman barang, yaitu kantor pusat di Pawulan, Colomadu dan gudang yang terletak di dekat Bandara Adi Sumarmo.

Berdasarkan faktor - faktor penyebab terjadinya keterlambatan pengiriman barang tersebut, dilakukan perbaikan terhadap salah satu faktor penyebab keterlambatan pengiriman barang, yaitu terdapat dua tempat pengiriman barang. Perbaikan dilakukan dengan cara menentukan lokasi yang paling baik untuk dijadikan lokasi kantor pengiriman barang. Perusahaan memerlukan alat bantu dalam menentukan lokasi kantor yang tepat untuk dijadikan tempat pengiriman barang dengan mempertimbangkan beberapa kriteria yang ditetapkan oleh perusahaan.

Terdapat banyak metode sistem pendukung keputusan yang dapat digunakan, salah satunya adalah metode AHP (Analytical Hierarchy Process) (Fizal, 2012). Metode ini dapat mengambil suatu keputusan yang efektif atas persoalan yang kompleks dengan jalan menyederhanakan dan mempercepat proses pengambilan keputusan (Fizal, 2012). Metode AHP merupakan metode yang memecah suatu masalah yang kompleks dan tidak terstruktur ke dalam kelompokkelompok, mengatur kelompok-kelompok tersebut ke dalam suatu susunan hirarki, memasukkan nilai numeris sebagai pengganti persepsi manusia dalam melakukan perbandingan relatif, dan akhirnya dengan suatu sintesis ditentukan elemen mana yang mempunyai prioritas tertinggi (Permadi, 1992). Proses penentuan tempat pengiriman barang menggunakan metode AHP berdasarkan empat kriteria, yaitu jarak dengan gudang utama (gudang dekat pesawat di Bandara Adi Sumarmo), kemudahan akses oleh pelanggan, luas bangunan, dan ketersediaan sarana dan prasarana. Hasil dari penelitian dengan menggunakan metode ini akan memberikan alternatif lokasi mana yang menjadi prioritas untuk dijadikan sebagai tempat pengiriman barang berdasarkan kriteria-kriteria yang telah ditetapkan.

Dari latar belakang masalah di atas, rumusan masalah yang dapat dibuat adalah dimana lokasi yang tepat untuk dijadikan lokasi kantor tempat pengiriman barang PT. Monang Sianipar Abadi (MSA Kargo) Surakarta yang sesuai dengan kriteria yang ditentukan oleh perusahaan ?

\section{Tinjauan Pustaka}

Metode AHP merupakan metode yang memecah suatu masalah yang kompleks dan tidak terstruktur ke dalam kelompok-kelompok, mengatur kelompok-kelompok tersebut ke dalam suatu susunan hirarki, memasukkan nilai numeris sebagai pengganti persepsi manusia dalam melakukan perbandingan relatif, dan akhirnya dengan suatu sintesis ditentukan elemen mana yang mempunyai prioritas tertinggi (Permadi, 1992).

Analytic Hierarchy Process (AHP) adalah suatu metode yang dapat menyelesaikan suatu permasalahan yang kompleks. Permasalahan tersebut dipecahkan ke dalam kelompok kelompok. Kemudian kelompok - kelompok tersebut diatur menjadi hirarki (Kusumadewi, 2003).

Keuntungan dari metode AHP adalah pada tahap akhir daat ditarik suatu konsensus yang merupakan gabungan pendapat dari seluruh pihak yang dijadikan narasumber (expert) (Fewidarto, 1988).

AHP sering digunakan sebagai metode pemecahan masalah dibanding dengan metode yang lain. Hal tersebut disebabkan :

1. Struktur AHP yang berhierarki, sebagai konsekuesi dari kriteria yang dipilih, sampai pada subkriteria yang paling dalam.

2. AHP memperhitungkan validitas sampai dengan batas toleransi inkonsistensi berbagai kriteria dan alternatif yang dipilih oleh pengambil keputusan.

3. AHP memperhitungkan daya tahan output analisis sensitivitas pengambilan keputusan. 
Prinsip-prisip dasar metode AHP (Saaty, 1980), yaitu:

1. Decomposition adalah memecahkan atau membagi problema yang utuh menjadi unsurunsurnya ke bentuk hirarki proses pengambilan keputusan, dimana setiap unsure atau elemen saling berhubungan.

2. Comparative Judgement, dilakukan dengan penilaian tentang kepentingan relative dua elemen pada suatu tingkat tertentu dalam kaitannya dengan tingkatan diatasnya.

3. Synthesis of Priority, dilakukan denga menggunakan eigen vector method untuk mendapatkan bobot relative bagi unsur-unsur pengambilan keputusan.

4. Logical Consistency, merupakan karakteristik penting AHP. Hal ini dicapai dengan mengagresikan seluruh eigen vector yang diperoleh dari berbagai tingkatan hirarki dan selanjutnya diperoleh suatu vector composite tertimbang yang menghasilkan urutan pengambilan keputusan.

Ada empat aksioma yang harus diperhatikan di dalam pemakaian metode AHP dan pelanggaran dari setiap aksioma akan berakibat tidak validnya mrtode yang dipakai (Permadi, 1992). Keempat aksioma tersebut, antara lain :

1. Reciprocal comparison

Pengambil keputusan harus mampu membuat perbandingan dan menentukan preferensinya.

2. Homogeneity

Preferensi seseorang harus dapat dinyatakan dalam skala terbatas atau elemenelemennya dapat diperbandingkan satu sama lain.

3. Independence

Preferensi dinyatakan dengan mengasumsikan bahwa kriteria tidak dipengaruhi oleh alternatif-alternatif yang ada melainkan oleh objektif secara keseluruhan.

4. Expectations

Untuk tujuan pengambilan keputusan, struktur hirarki diasumsikan lengkap. Pengolahan data menggunakan metode AHP didasarkan pada skala perbandingan multi-item yang dirancang untuk mengukur tingkat kepentingan antar kriteria dan alternatif. Pengolahan data AHP terdiri dari :

1. Penghitungan geometric mean untuk setiap kriteria/subkriteria dan alternatif dengan rumus:

Geomeric Mean $=a_{i j}=\left(Z_{1}, Z_{2}, Z_{3}, \ldots . ., Z_{n}\right)^{1 / n}$

2. Menghitung matriks perbandingan berpasangan untuk kriteria/subkriteria dan alternatif terhadap setiap kriteria/subkriteria .

3. Perhitungan eigen vector untuk kriteria/subkriteria dan setiap alternatif lokasi dengan rumus:

$E V=\frac{\sum\left(\frac{\text { Jumlahvektorbaris }}{\text { Jumlahnilaikolom }}\right)}{n}$

4. Perhitungan eigen value untuk tujuan dan kriteria/subkriteria dengan rumus:

Eigen value $(\lambda \max )=\sum$ (jumlah kolom $x$ jumlah bobot)

5. Perhitungan uji konsistensi dengan rumus:

$$
\begin{aligned}
& C I_{1}=\frac{(\lambda \max -n)}{n-1} \\
& C R_{1}=\frac{C I_{1}}{R I_{1}}
\end{aligned}
$$


6. Pengujian konsistensi hirarki dengan rumus:

$$
C R H=\frac{C_{c i}}{C_{r i}}
$$

Proses Penghitungan AHP.

Pertama-tama menyusun hirarki dimana diawali dengan tujuan, kriteria dan alternatif-alternatif calon pada tingkat paling bawah. Selanjutnya menetapkan perbandingan berpasangan antara kriteria-kriteria dalam bentuk matrik nilai diagonal matrik untuk perbandingan suatu elemen dengan elemen itu sendiri diisi dengan bilangan satu sedangkan isi nilai perbandingan antara satu sampai dengan sembilan kebalikannya, kemudian dijumlahkan perkolom data matrik.

\section{Metode Penelitian}

Metode yang digunakan yaitu metode deskriptif untuk menggambarkan fakta saat ini, berkaitan dengan opini, kejadian atau prosedur berdasarkan pada objek pengamatan. Metode yang sering dipakai adalah metode survey (Kuncoro, 2007). Satuan pengamatan adalah satuan tempat untuk memperoleh informasi tentang satuan analisis (W. Gulo, 2005). Satuan pengamatan dalam penelitian ini adalah PT. Monang Sianipar Abadi (MSA) Kargo Surakarta.

Jenis data yang digunakan dalam penelitian ini adalah data primer untuk penentuan tempat pengiriman barang yang diperoleh dari hasil wawancara dengan karyawan PT. Monang Sianipar Abadi (MSA Kargo) Surakarta dan data sekunder merupakan data sarana dan prasarana, jarak dengan gudang utama, dan luas bangunan pada kedua tempat pengiriman barang.

Selanjutnya dilakukan pemilihan lokasi pengiriman barang PT. Monang Sianipar Abadi (MSA Kargo) Surakarta yang tepat sesuai dengan kriteria yang diinginkan dengan menggunakan metode Analytical Hierarchy Process (AHP) yaitu dengan melakukan penyebaran kuesioner kepada empat karyawan PT. MSA Kargo Surakarta. Tahap terpenting pada AHP adalah penilaian dengan teknik perbandingan berpasangan terhadap aktor - aktor pada suatu tingkat hirarki. Penilaian dengan memberikan bobot numerik dan membanding satu elemen dengan elemen lainnya. Kemudian melakukan sintesa terhadap hasil untuk menentukan elemen yang memilki prioritas tertinggi dan terendah. Kemudian akan diperoleh alternatif lokasi yang memiliki bobot tertinggi, maka akan diperoleh lokasi yang tepat untuk pengiriman barang PT. Monang Sianipar Abadi (MSA Kargo) Surakarta.

Setelah diketahui beberapa faktor penentuan lokasi, selanjutnya dilakukan pengolahan data untuk mengetahui faktor yang paling berpengaruh. Pengolahan data tersebut menggunakan metode Analytical Hierarcy Process (AHP) dengan pendekatan perbandingan berpasangan. Perbandingan berpasangan sering digunakan untuk menentukan kepentingan relatif dari elemen dan kriteria yang ada (Dewa, 2011). Perbandingan berpasangan tersebut diulang untuk semua elemen dalam tiap tingkat. Elemen dengan bobot paling tinggi adalah pilihan keputusan yang layak dipertimbangkan untuk diambil. Menurut Saaty (1986) untuk berbagai permasalahan skala 1 sampai dengan 9 merupakan skala terbaik dalam mengkualitatifkan pendapat. Oleh karena itu, skala perbandingan berpasangan didasarkan pada nilai-nilai fundamental AHP dengan pembobotan dari nilai 1 untuk sama penting sampai 9 untuk sangat penting sekali. 


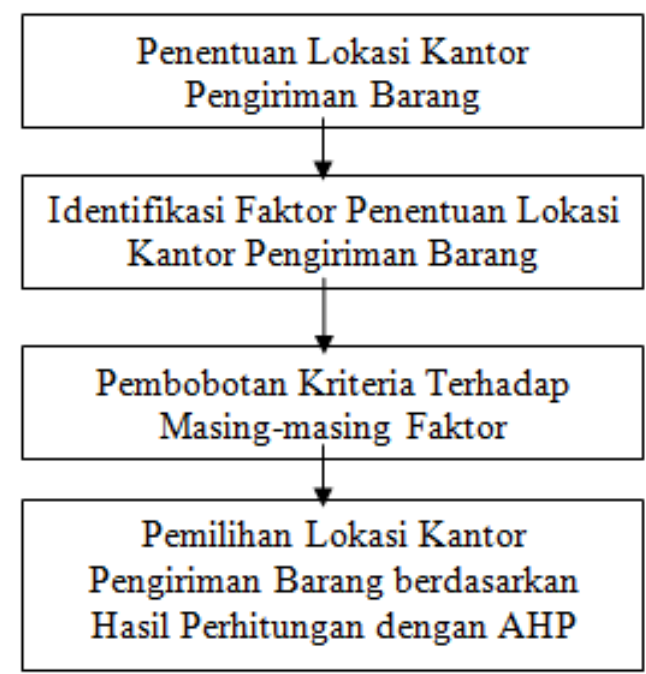

Gambar 1. Alur Metode dalam Penelitian

\section{Hasil dan Pembahasan}

Manurut Hindrayani (2010), beberapa pertimbangan dan faktor yang mempengaruhi keputusan lokasi digambarkan sebagai berikut:

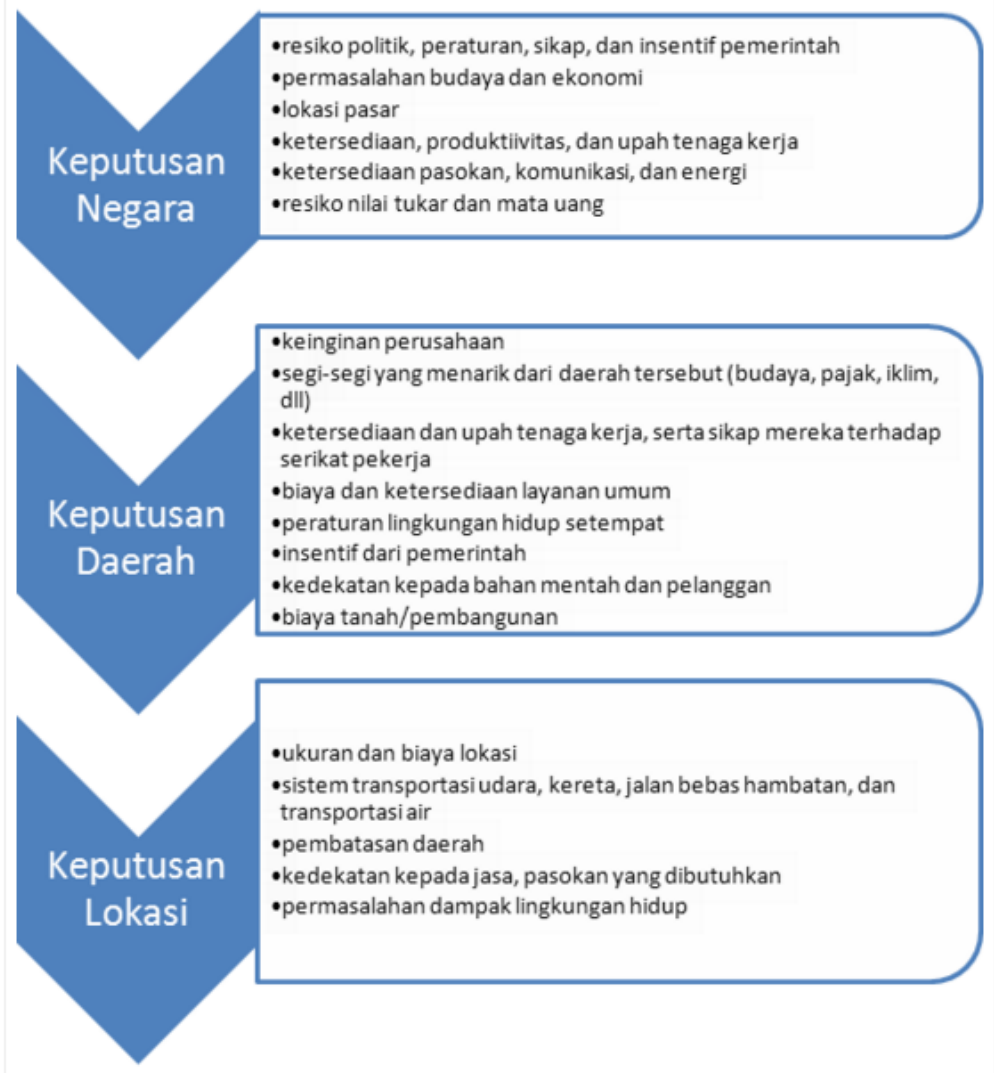

Berdasarkan sumber diatas kemudian pada penentuan lokasi ini, ditentukan beberapa kriteria yang sesuai dengan kondisi perusahaan. Kriteria-kriteria ini disusun berdasarkan hasil wawancara dan diskusi dengan karyawan PT. MSA Kargo Surakarta. Dari beberapa kriteria yang ditetapkan kemudian melakukan perbandingan antara kriteria yang satu dengan kriteria yang lainnya sesuai dengan skala perbandingan. Setelah itu baru melakukan perbandingan terhadap masing-masing kriteria. Adapun kriteria yang ditetapkan disajikan pada Tabel 1. 
Tabel 1. Kriteria-kriteria yang ditetapkan

\begin{tabular}{clc}
\hline No & \multicolumn{1}{c}{ Kriteria } & Kode \\
\hline 1 & Jarak dengan gudang utama & A \\
2 & Kemudahan akses oleh pelanggan & B \\
3 & Luas bangunan & C \\
4 & Ketersediaan sarana dan prasarana & D \\
\hline
\end{tabular}

Dalam AHP diawali dengan menyusun hirarki yang meliputi tujuan, kriteria dan alternatif-alternatif lokasi pada tingkat paling bawah. Selanjutnya menetapkan perbandingan berpasangan antara kriteria-kriteria dalam bentuk matrik. Data matrik tersebut seperti pada Tabel 2.

Tabel 2. Matriks Perbandingan Kriteria

\begin{tabular}{ccccc}
\hline & $\mathrm{A}$ & $\mathrm{B}$ & $\mathrm{C}$ & $\mathrm{D}$ \\
\hline $\mathrm{A}$ & 1,00 & 0,33 & 5,00 & 3,00 \\
$\mathrm{~B}$ & 3,00 & 1,00 & 7,00 & 5,00 \\
$\mathrm{C}$ & 0,20 & 0,14 & 1,00 & 0,20 \\
$\mathrm{D}$ & 0,33 & 0,20 & 5,00 & 1,00 \\
\hline Jumlah & 4,53 & 1,68 & 18,00 & 9,20 \\
\hline
\end{tabular}

Setelah terbentuk matrik perbandingan maka dilihat bobot prioritas untuk perbandingan kriteria. Dengan cara membagi isi matriks perbandingan dengan jumlah kolom yang bersesuaian, kemudian menjumlahkan perbaris. Untuk menemukan bobot prioritas maka hasil penjumlahan tersebut dibagi dengan banyaknya kriteria. Adapun nilai bobot prioritas disajikan pada Tabel 3 .

Tabel 3. Matriks Bobot Prioritas Kriteria

\begin{tabular}{ccccccc}
\hline & A & B & C & D & Jumlah & Bobot Prioritas \\
\hline A & 0,221 & 0,199 & 0,278 & 0,326 & 1,023 & 0,256 \\
B & 0,662 & 0,597 & 0,389 & 0,543 & 2,191 & 0,548 \\
C & 0,044 & 0,085 & 0,056 & 0,022 & 0,207 & 0,052 \\
D & 0,074 & 0,119 & 0,278 & 0,109 & 0,579 & 0,145 \\
\hline
\end{tabular}

Untuk mengetahui konsisten matriks perbandingan dilakukan perkalian seluruh isi kolom matriks A perbandingan dengan bobot prioritas kriteria A, isi kolom B matriks perbandingan dengan bobot prioritas kriteria B dan seterusnya. Kemudian dijumlahkan setiap barisnya dan dibagi penjumlahan baris dengan bobot prioritas bersesuaian seperti pada Tabel 4 .

Tabel 4. Matriks Konsistensi Kriteria

\begin{tabular}{ccccccc}
\hline & A & B & C & D & Jumlah & Bobot \\
\hline A & 0,256 & 0,183 & 0,258 & 0,434 & 1,131 & 4,422 \\
B & 0,767 & 0,548 & 0,362 & 0,724 & 2,401 & 4,384 \\
C & 0,051 & 0,078 & 0,052 & 0,029 & 0,210 & 4,066 \\
D & 0,085 & 0,110 & 0,258 & 0,145 & 0,598 & 4,129 \\
\hline
\end{tabular}

$$
\begin{aligned}
\text { Hitung } \lambda_{\text {maksimum }} & =(4,422+4,384+4,066+4,129) / 4 \\
& =17 / 4 \\
& =4,250 \\
\text { Hitung CI } & =\left(\lambda_{\text {maksimum }}-\mathrm{n}\right) /(\mathrm{n}-1)
\end{aligned}
$$




$$
\begin{aligned}
& =(4,250-4) /(4-1) \\
& =0,250 / 3 \\
& =0,08331
\end{aligned}
$$

Hitung CR $=\mathrm{CI} / \mathrm{RI} \quad=0,08331 / 0,9$

$$
=0,09256 \text {, karena } \mathrm{CR}<0,1 \text { maka perbandingan konsisten } 100 \% \text {. }
$$

Setelah menemukan bobot prioritas kriteria, menetapkan nilai skala perbandingan lokasi berdasarkan masing-masing kriteria. Langkah selanjutnya membuat matriks perbandingan alternatif lokasi berdasarkan kriteria. Setelah terbentuk matriks perbandingan lokasi berdasarkan kriteria maka dicari bobot prioritas untuk perbandingan lokasi terhadap masing-masing kriteria. S1 adalah kantor dekat Bandara Adi Sumarmo dan S2 adalah kantor di Pawulan, Colomadu.

Matriks perbandingan alternatif lokasi kantor berdasarkan pertimbangan kriteria jarak dengan gudang utama, disajikan pada Tabel 5.

Tabel 5. Matriks Perbandingan Alternatif Lokasi Kantor Berdasarkan Pertimbangan Kriteria Jarak Dengan Gudang Utama

\begin{tabular}{ccc}
\hline A & S1 & S2 \\
\hline S1 & 1 & 3 \\
S2 & 0,333 & 1 \\
\hline Jumlah & 1,333 & 4 \\
\hline
\end{tabular}

Matriks bobot prioritas lokasi kantor berdasarkan pertimbangan kriteria jarak dengan gudang utama disajikan pada Tabel 6.

Tabel 6. Matriks Bobot Prioritas Lokasi Kantor Berdasarkan Pertimbangan Kriteria Jarak Dengan

\begin{tabular}{ccccc}
\multicolumn{5}{c}{ Gudang Utama } \\
\hline A & S1 & S2 & Jumlah & Bobot \\
\hline S1 & 0,75 & 0,75 & 1,5 & 0,75 \\
S2 & 0,25 & 0,25 & 0,5 & 0,25 \\
\hline
\end{tabular}

Matriks perbandingan alternatif lokasi kantor berdasarkan pertimbangan kriteria kemudahan akses oleh pelanggan, disajikan pada Tabel 7.

Tabel 7. Matriks Perbandingan Alternatif Lokasi Kantor Berdasarkan Pertimbangan Kriteria

\begin{tabular}{ccc}
\multicolumn{3}{c}{ Kemudahan } \\
\hline B & S1 & S2 2 \\
\hline S1 & 1 & 0,333 \\
S2 & 3 & 1 \\
\hline Jumlah & 4 & 1,333 \\
\hline
\end{tabular}

Matriks bobot prioritas lokasi kantor berdasarkan pertimbangan kriteria kemudahan akses oleh pelanggan disajikan pada Tabel 8 .

Tabel 8. Matriks Bobot Prioritas Lokasi Kantor Berdasarkan Pertimbangan Kriteria Kemudahan Akses Oleh Pelanggan

\begin{tabular}{ccccc}
\hline B & S1 & S2 & Jumlah & Bobot \\
\hline S1 & 0,25 & 0,25 & 0,5 & 0,25 \\
S2 & 0,75 & 0,75 & 1,5 & 0,75 \\
\hline
\end{tabular}

Matriks perbandingan alternatif lokasi kantor berdasarkan pertimbangan kriteria luas bangunan, disajikan pada Tabel 9 . 
Tabel 9. Matriks Perbandingan Alternatif Lokasi Kantor Berdasarkan Luas Bangunan

\begin{tabular}{ccc}
\hline C & S1 & S2 \\
\hline S1 & 1 & 0,2 \\
S2 & 5 & 1 \\
\hline Jumlah & 6 & 1,2 \\
\hline
\end{tabular}

Matriks bobot prioritas lokasi kantor berdasarkan pertimbangan kriteria luas bangunan disajikan pada Tabel 10.

Tabel 10. Matriks Bobot Prioritas Lokasi Kantor Berdasarkan Pertimbangan Kriteria luas Bangunan

\begin{tabular}{ccccc}
\hline C & S1 & S2 & Jumlah & Bobot \\
\hline S1 & 0,167 & 0,167 & 0,333 & 0,167 \\
S2 & 0,833 & 0,833 & 1,667 & 0,833 \\
\hline
\end{tabular}

Matriks perbandingan alternatif lokasi kantor berdasarkan pertimbangan kriteria ketersediaan sarana dan prasarana, disajikan pada Tabel 11.

Tabel 11. Matriks Perbandingan Alternatif Lokasi Kantor Berdasarkan Kriteria Ketersediaan Sarana dan Prasarana

\begin{tabular}{ccc}
\hline $\mathrm{D}$ & $\mathrm{S} 1$ & $\mathrm{~S} 2$ \\
\hline $\mathrm{S} 1$ & 1 & 0,2 \\
$\mathrm{~S} 2$ & 5 & 1 \\
\hline Jumlah & 6 & 1,2 \\
\hline
\end{tabular}

Matriks bobot prioritas lokasi kantor berdasarkan pertimbangan kriteria ketersediaan sarana dan prasarana disajikan pada Tabel 12.

Tabel 12. Matriks Bobot Prioritas Lokasi Kantor Berdasarkan Pertimbangan Kriteria Ketersediaan Sarana dan Prasarana

\begin{tabular}{ccccc}
\hline D & S1 & S2 & Jumlah & Bobot \\
\hline S1 & 0,167 & 0,167 & 0,333 & 0,167 \\
S2 & 0,833 & 0,833 & 1,667 & 0,833 \\
\hline
\end{tabular}

Setelah menemukan bobot dari masing-masing kriteria terhadap lokasi yang sudah ditentukan, langkah selanjutnya adalah mengalikan bobot dari masing-masing kriteria dengan bobot dari masing-masing lokasi, kemudian hasil perkalian tersebut dijumlahkan perbaris. Sehingga didapatkan total prioritas global seperti pada Tabel 13.

Tabel 13. Matrik Total Prioritas Global

\begin{tabular}{cccccc}
\hline & A & B & C & D & Total Prioritas Global \\
\hline S1 & 0,192 & 0,137 & 0,009 & 0,024 & 0,362 \\
S2 & 0,064 & 0,411 & 0,043 & 0,121 & 0,638 \\
\hline
\end{tabular}

Setelah diketahui total prioritas global masing - masing lokasi, maka dapat ditentukan lokasi yang paling baik untuk dijadikan kantor pengiriman barang. Lokasi yang dipilih untuk lokasi kantor pengiriman barang memiliki kekurangan yaitu jaraknya cukup jauh dari gudang utama sehingga dapat ditambahkan solusi yaitu dengan melakukan penambahan armada untuk pengiriman barang agar jumlah barang yang dapat dibawa untuk dikirim ke gudang utama lebih banyak dari sebelumnya. 


\section{Simpulan}

Berdasarkan hasil total prioritas global yang diperoleh, maka dapat diambil keputusan lokasi yang paling baik dalam penentuan lokasi kantor adalah lokasi S2 yaitu kantor di Pawulan, Colomadu karena mempunyai total prioritas global tertinggi, yaitu 0,638. Namun, lokasi tersebut memiliki kekurangan yaitu jaraknya cukup jauh dari gudang utama sehingga dapat ditambahkan solusi dengan melakukan penambahan armada untuk pengiriman barang.

Penelitian berikutnya dapat menentukan lokasi kantor pengiriman barang yang tepat dengan menambahkan faktor-faktor yang lain. Sehingga kesimpulan yang dihasilakan lebih lengkap dan dapat memudahkan perusahaan dalam menjalankan bisnisnya.

\section{Daftar Pusaka}

Dewa, I. A. (2011). Penentuan Skala Prioritas Penanganan Jalan Kabupaten di Kabupaten Bangli. Denpasar : Universitas Udayana.

Donoriyanto, D. S. (n.d.). Analisis Kualitas Pelayanan Jasa Pengiriman Barang dengan Metode Servqual dan QFD di PT. APAS, Teknik Industri FTI, UPNV Jawa Timur

Dzulfikri. (2013). Penentuan Lokasi Pabrik dalam Rencana untuk Perluasan Perusahaan (Studi di PT 3 M Indonesia dengan Sistem Proses Hirarki Analitik), Manufacturing Professional PT 3 M Indonesia, Vol. 11, pp. 161-176

Faizal, Edi. (2012). Model Analisis Kelayakan Lokasi Minimarket dengan Metode Analytical Hierarchy Process, STMIK El Rahma, Vol. 10, pp. 1-12

Gulo, W. (2005). Metodologi Penelitian. Jakarta : PT Grasindo.

Hindriyani, Aniek. (2010). Manajemen Operasi. Yogyakarta: Pohon Cahaya.

Hutagaol, V., Sudarsono, B. dan Nugraha, A. L. (2015). Penentuan Potensi Lokasi ATM BNI Menggunakan Analytical Hierarchy Process (AHP) dan Sistem Informasi Geografis (Studi Kasus : Kecamatan Tembalang), Program Studi Teknik Geodesi, Fakultas Teknik, Universitas Diponegoro, Vol. 4, pp. 25-32

Kuncoro, M. (2007). Metode Kuantitatif Teori dan Aplikasi untuk Bisnis dan Ekonomi. Jakarta : PT Gramedia Widia Sarana Indonesia.

Kurniawan, A. dan Murtiningrum. (2013). Penentuan Lokasi Industri Pala Papua Berdasarkan Proses Hierarki Analitik (Analytic Hierarchy Process) dan Aplikasi Sistem Penunjang Keputusan (SPK) di Kabupaten Fakfak, Jurusan Teknologi Pertanian, Fakultas Pertanian dan Teknologi Pertanian (Fapertek), Universitas Negeri Papua (UNIPA), Vol. 7, pp. 103-107

Revano, R. dan Herlambang, D. (1978). Sistem Pendukung Keputusan untuk Pembelian Mobil Merek Toyota Menggunakan Analytic Hierarchy Process, Jurusan Sisitem Informasi, STIKOM Surabaya, Vol. II, pp. 61-65

Saaty, T.L. (1986). Proses Hirarki Analitik untuk Pengambilan Keputusan Dalam Situasi yang Kompleks. Jakarta : PT Pustaka Binman Pressindo.

Susanto, T. dan Sarwadi, (n.d.).Optimasi Produksi dan Pengendalian Bahan Baku Studi Kasus pada PT. Joshua Indo Export, Jurusan Matematika FMIPA UNDIP

Utama, M. R., Rukmi,H. S. dan Adianto, R. H. (2014). Usulan Pemilihan Lokasi National Conference AIESEC LC Bandung dengan Menggunakan Metode Analytical Hierarchy Process, Jurusan Teknik Industri, Institut Teknologi Nasional (Itenas), Bandung, Vol. 01, pp. 254-262

Winiarti, S. dan Yuraida, U. (2009). Aplikasi Sistem Pendukung Keputusan Penentuan Lokasi Pendirian Warnet dengan Metode Analytical Hierarchy Process (AHP) (Studi Kasus : PT. Pika Media Komunika), Program Studi Teknik Informatika, Fakultas Teknologi Industri Universitas Ahmad Dahlan Yogyakarta, Vol. 3, pp. 311-322 